\title{
Prosecution for Violations of International Humanitarian Law: Russia's Position
}

Larisa V. Deriglazova, Olga Yu. Smolenchuk

\author{
Larisa V. Deriglazova, DSc (History) \\ Tomsk State University, Tomsk, Russia \\ Department of World Politics \\ Professor; \\ Head of the Jean Monnet Centre for European Studies (CEES), Tomsk State University \\ ORCID: 0000-0003-4577-6163 \\ E-mail: larisa.deriglazova@mail.tsu.ru \\ Tel.: +7 9131170364 \\ Address: 36 Lenin Prospect, Tomsk 634050, Russia \\ Olga Yu. Smolenchuk, PhD in History \\ Tomsk State University, Tomsk, Russia \\ Department of Anthropology and Ethnology \\ Associate Professor; \\ Fellow at the Jean Monnet Centre for European Studies (CEES), Tomsk State University \\ ORCID: 0000-0003-2400-7306 \\ E-mail: smolenchuk@gmail.com \\ Tel.: + 79039534886 \\ Address: 34 Lenin Prospect, Tomsk 634050, Russia
}

The reported study was funded by RFBR, Project 19-114-50043.

The authors thank G.I. Bogush, , G.A. Yesakov, N.A. Sokolova, and anonymous reviewers for their comments and criticism that helped to specify our position and eliminate inaccuracies. The authors would like to thank particularly Anastasia Kushleyko, International Committee of the Red Cross, and Xabier Agirre Aranburu, International Criminal Court, for their professional and amicable support, without which this project would hardly be possible.

DOI: $10.31278 / 1810-6374-2021-19-4-198-225$ 


\section{Abstract}

Russia's official position regarding the prosecution for violations of International Humanitarian Law (IHL) in international criminal courts changed during the 1990s and the 2000s. The article studies the reasons for these changes by reviewing works of Russian experts. The performance of the International Criminal Tribunal for the former Yugoslavia (ICTY) had a negative impact on Russia's position. Russian experts questioned the impartiality of the ICTY and its effectiveness in preventing such crimes and reconciling the parties.

Russia's position has also changed with regard to the International Criminal Court (ICC). In 2000, the Russian Federation signed the Rome Statute that established the ICC, but withdrew its signature in November 2016. One of the reasons for that decision was the participation of Russian troops in armed conflicts outside of the Russian Federation and outside of UN peacekeeping missions. Russian experts emphasize that IHL norms are enforced primarily at the national level, which means that Russia can make its own decisions regarding criminal prosecution for IHL violations.

Keywords: Russia, International Humanitarian Law (IHL), International Criminal Tribunal for the former Yugoslavia (ICTY), International Criminal Court (ICC), international crimes.

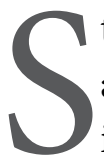

tudying Russia's position on International Humanitarian Law and international prosecution for its violations is relevant and important for several reasons. In the pre-Soviet period, Russia played a leading role in establishing IHL norms. At the 1899 Hague Peace Conference, which came from a proposal by Russian Tsar Nicholas II and set the foundations of modern IHL, Russian lawyer Fyodor Martens chaired the committee that worked on "The Hague Convention on the Laws and Customs of War on Land." The USSR also played an important role in organizing the Nuremberg and Tokyo Tribunals after the end of World War II. The contribution of Russian and Soviet lawyers to the development of IHL is recognized throughout the world (see, for example, Hirsch, 2020). In the 1990s, Russia supported the creation of UN international criminal tribunals 
to prosecute IHL violations, and in September 2000, Russia signed the Rome Statute that established the International Criminal Court. However, in the 2000s, Russia increasingly defended the right to sovereign prosecution for IHL violations and did not join the work of the permanent International Criminal Court. A comprehensive approach to understanding Russia's position on international criminal justice and the reasons for its change is important since the Russian Federation is one of the founders of the modern system of international relations and a guarantor of international security.

International prosecution for IHL violations sparks fierce debates and emotional reactions among politicians, experts, and public at large. After the end of the Cold War, the international community came to a fragile consensus on the need for violations of IHL norms and values to be prosecuted internationally. In 1993 and 1994, the UN Security Council adopted resolutions establishing two tribunals intended to investigate war crimes, the crime of genocide, and crimes against humanity committed during the war in the former Yugoslavia, and the massacre of the Tutsi minority in Rwanda in the first half of 1994. The International Criminal Tribunal for the former Yugoslavia (ICTY) and the International Criminal Tribunal for Rwanda (ICTR) were established as ad hoc tribunals and had limited jurisdiction in both time and territory. After the Nuremberg and Tokyo trials, these UN tribunals were the first attempt at international criminal prosecution of persons involved in organizing and executing massacres, torture, violence and inhuman treatment of civilians, the wounded, and prisoners of war. At an international conference organized by the UN in 1998 in Rome, 120 countries voted for adopting a document establishing a permanent International Criminal Court. The Rome Statute entered into force in 2002 after ratification by sixty countries. The ICC began operation in The Hague in 2003 and held its first hearings in 2006.

However, the international community's consensus on the need to act through the system of international criminal courts was not only fragile but also short-lived. Often, both sides of the process assess the work of international courts negatively. Victims of war crimes, who seek justice, criticize the process for being too long, complex 
and distressful, and challenge court decisions. Those accused of war crimes rarely recognize themselves as war criminals and emphasize the noticeably politicized nature of the tribunals. Other participants in the trials-witnesses, experts, and lawyers-complain about the way the proceedings are organized. Proponents of international prosecution of war criminals stress that the long-term goal of international criminal courts is to prevent such crimes in the future, restore justice and reconcile previously warring parties, but in real life international justice does not always produce the desired results (Snyder and Vinjamuri, 2004; Deriglazova, 2007).

Relations between the countries of the former Yugoslavia that fought in the war in 1991-1995 remain strained, and their complaints against the international community for convictions or acquittals persist. A vivid example of such an attitude is the criminal proceedings against former Kosovo President Hashim Thaçi launched in June 2020 by the Hague-based Kosovo Specialist Prosecutor's Office. This decision provoked a sharp negative reaction in Kosovo even though as far back as 2005 former ICTY chief prosecutor Carla Del Ponte had indicted commanders of the Kosovo Liberation Army for war crimes (Del Ponte, 2005). The work of the International Criminal Tribunal for Rwanda was also accompanied by problems and did not lead to sustainable peace in the region.

Influential countries such as the United States, Russia, China, India, Pakistan, and Israel do not participate in the work of the International Criminal Court. Its critics say that the court prosecutes mostly representatives of African countries, but citizens of developed and actively warring countries are unlikely to stand trial as accused. Only recently, the ICC initiated preliminary examinations of the situation in South Ossetia (Georgia), Ukraine, Afghanistan, and Palestine, which immediately provoked a negative official reaction in the United States, Russia, and Israel. In November 2016, Russia informed the UN Secretary General of its intention "not to become a party to the Rome Statute of the International Criminal Court." In 2020 the United States imposed sanctions against the ICC Prosecutor and some of her senior staff members as she was planning 
investigations that might possibly affect officers of the United States and Israel (U.S. Sanctions, 2020). The U.S. lifted these sanctions in 2021, after the election of President Joe Biden.

Although Russia is the legal successor of the USSR, it is nevertheless a completely different political and foreign policy actor with a different set of goals and a different attitude towards international institutions and norms. While recognizing the importance of abiding by international law in general and IHL norms in particular, the Russian Federation assesses the work of international tribunals and the ICC critically. Constitutional amendments approved in a nationwide referendum on July 1, 2020, allow Russia to ignore decisions of interstate bodies if they contradict its Constitution. This amendment attracted the attention of foreign experts even before the vote as a sign of Russia's purported departure from its international obligations (Venice Commission, 2020).

The purpose of the article is to determine the reasons for the change in Russia's official position on international criminal courts. The research method involves an analysis of Russian academic publications on the prosecution of IHL violations through the system of international criminal courts after 1991. The study proposes the hypothesis that the change in Russia's official position is caused by a set of reasons, including: 1) the experience of Russian experts' work in international courts; 2) the changing context of international justice, and 3) the nature of Russia's relations with the outside world in the past two decades.

We searched relevant works using keywords in Russian-language academic databases. The publications included a variety of educational materials and tutorials for universities, indicating the growing interest in international law in Russia in recent decades (See, for example, Kuznetsov and Tuzmukhamedov, 2010; Bogush et al., 2019). A large number of translations by the International Committee of the Red Cross were also made in the same period. Reference and educational materials were later excluded from the initial list of works.

The final list of works included about 500 publications, which can be divided into three groups. The first group (more than 200 publications) discusses IHL norms as part of international law, 
their correlation with international criminal law and human rights law, as well as the relationship between international law and the national legal system. The second group of publications examines the experience of UN international courts and tribunals, including the historical Nuremberg and Tokyo tribunals (73 publications), the ICTY (more than 100 works), and single works concerning other international tribunals. The third group (more than 120 publications) is focused entirely on the International Criminal Court, its work and the possibility of ratification of its Rome Statute by Russia. We tried to take into account English-language works by Russian experts, but their number is quite small (see, for example, Vasiliyev and Ogorodova, 2005; Nelaeva, 2010; Marochkin and Nelaeva, 2015, 2016; Yesakov, 2017; Tuzmukhamedov, 2019). Lawyers make up the largest group of experts in the sample, followed by historians and political scientists. There are also several publications by Russian diplomats, politicians, and military officers who took part in the work of international courts as witnesses or observers.

Russian experts in this field include representatives of at least two generations, many of whom have a $\mathrm{PhD}$ in Law and work in higher educational institutions in Moscow, including universities that train international cooperation specialists, such as MGIMO, RUDN, and the Diplomatic Academy. There is also a noticeable share of experts working in other cities. More than two dozen doctoral dissertations have been defended on the topic of International Humanitarian Law (links to some of them can be found in the References list available in the online version of this article). Undoubtedly, this signifies professional interest in this topic and the need for such expertise in Russia at the government level.

The article presents an analysis of publications on the work of (1) UN ad hoc international tribunals and (2) the International Criminal Court. The list of cited works includes only part of the publications due to the limitations of the magazine article format. We did not consider numerous publications focusing on the integration of IHL norms into Russian criminal legislation since this topic requires a separate study, especially considering the ongoing intense debate; nor 
did we analyze works exploring historical aspects of IHL development and the Nuremberg and Tokyo Tribunals since these works, with few exceptions (Mezyaev, 2011; Volevodz, 2016), are not directly related to the subject matter of this article.

\section{EVALUATING THE WORK OF UN INTERNATIONAL CRIMINAL TRIBUNALS}

In Russia, the attitude towards international criminal justice was shaped mainly by the work of the International Criminal Tribunal for the former Yugoslavia and its assessment by Russian politicians, experts and the media. The work of the International Criminal Tribunal for Rwanda was covered to a much lesser extent even though it involved three Russian judges: Ya. A. Ostrovsky (1995-1997), S.A. Yegorov (20032010), and B.R. Tuzmukhamedov (2009-2012). The establishment of the ICTY was supported by Russia, which co-sponsored its founding resolution, and, according to S.A. Yegorov, "the Russian Federation made no reservations about such a procedure for creating the tribunal," and its establishment was considered a historical event (2014, p. 589). G.A. Nelaeva and Z.I. Gizatullina quote Yuly Vorontsov, the Russian representative to the UN Security Council at that time, as saying that "this is the first time in history when not the victors judge the defeated, but the entire international community judges those who violated the generally accepted norms of international law and human notions of morality and humanity" (2012, p. 74). The Russian government agreed to have several Russian lawyers and investigators joining the Office of the Prosecutor from the early days, including Nikolai Mikhailov (investigator in cases against Bosnian Muslims) and Vassily Poryvayev (lawyer in cases against Bosnian Croats).

Following NATO's operation in Kosovo in 1999, the Russian expert community assumed a pronounced anti-Western position, and many Russian authors began to speak about the limited legitimacy of the ICTY and even questioned the legality of its creation. Kh. F. Dzhantaev explains Russia's negative attitude towards the ICTY by mass violations

of IHL norms in Chechnya in the 1990s and the unwillingness of "the Russian leadership, especially Boris Yeltsin, to set an international 
precedent for convicting military leaders" (2013, p. 164). In June 1999, the State Duma created a special commission "to study and summarize information on crimes committed during the aggression of the North Atlantic Treaty Organization against the Federal Republic of Yugoslavia." The commission was headed by Nikolai Ryzhkov (Soviet prime minister in 1985-1991) and worked until 2003. Russian experts appeared at the ICTY as defense witnesses to testify in proceedings against Serbian military leaders and politicians. The book Defense Witnesses Speak. The Trial of Slobodan Milošević (2005), under the editorship of Nikolai Ryzhkov, contained, among other things, testimonies given at the ICTY by Yevgeny Primakov, former foreign minister and prime minister, Colonel-General Leonid Ivashov, and Slobodan Milošević. Russian diplomat Yevgeny Minin (2018) points out that Russian diplomats and experts managed to initiate ICTY proceedings against the NATO operation in Kosovo, although their results did not satisfy either Russia or Serbia.

Slobodan Miloševićs death on March 11, 2006 in a Hague prison before the end of the hearings in the case caused a negative reaction among Russians. Although Milošević had been accused of war crimes and held in prison since April 2001, 46\% of Russians considered him a true national leader who had acted in the interests of his country. In Moscow and St. Petersburg, 58\% of respondents shared this opinion. The same survey showed that $44 \%$ of respondents considered the work of the Tribunal biased and 39\% were undecided (VTsIOM, 2006). Miloševićs widow Mirjana Marković, having received refugee status, lived in Russia from 2003 until her death in 2019, and Russia refused to extradite her to the Serbian authorities in connection with the legal proceedings.

The main complaint Russian experts made about the ICTY was its partiality, since it prosecuted mainly ethnic Serbs, and Western countries played a major role in its work (Mikhailov, 2003; Nelaeva, 2007; Khaziev, 2016; Yesakov, 2017). This is borne out by statistics concerning initiated cases and delivered verdicts, as well as the composition of the Bench and the Tribunal Prosecutor's office. N.I. Mikhailov, who served as a team head in the investigation of 
the ICTY's Office of the Prosecutor in 1997-2003, wrote about the partiality of the ICTY $(2003,2006)$. Historian Yelena Guskova, who headed the Center for the Study of the Contemporary Balkan Crisis at the Institute of Slavic Studies of the Russian Academy of Sciences and took part in the work of the ICTY as an academic expert in defense of General Stanislav Galić, stated this position with the bluntness and severity of accusation. Guskova published a significant number of academic works on the Yugoslav conflict, and also gave interviews and made comments in the media on the investigation of "big cases" involving Slobodan Milošević, Radovan Karadžić, and Ratko Mladić (Guskova, 2003, etc., see the References section in the online version of the article). In 2004, Guskova refused to appear at the ICTY as a defense witness for Milošević in protest against the Tribunal's decision that prohibited him from defending himself and assigned its own attorneys to him.

Russian experts noted that the ICTY's partiality affected all its work, including the process of forming the Bench, the criminal litigation model (Anglo-Saxon, adversarial), the procedures for investigating, initiating or refusing to initiate criminal proceedings, expert support, and the work of interpreters for the accused (Guskova, 2003, 2012; Khaziev, 2016; Minin, 2018). Some Russian experts insisted that there were violations of the rights of detainees, including denial of medical care, violation of the fundamental principle of the presumption of innocence during the investigation, and the length of trials (Primakov, 2009; Minin, 2018).

A collective monograph edited by Yelena Guskova (2012) contains detailed criticism of the ICTY. The publication summarized the work of an international academic conference titled "Activity of the International Criminal Tribunal for the Former Yugoslavia: Content, Results, Effectiveness," which was held in 2009 at the Institute of Slavic Studies of the Russian Academy of Sciences. Conference participants questioned the legitimacy of the ICTY's establishment (Mezyaev), spoke of problems related to the way evidence was presented and witnesses and experts interviewed (Guskova), and pointed to violations of criminal procedure law. The section on Srebrenica (pp. 173-301) 
is worth mentioning separately as it basically challenges the fact of genocide. The overall conclusion drawn in this collective monograph is an unequivocal "guilty verdict" for the ICTY, which, according to the conference participants, was created illegally and was in breach of international law, thus damaging the system of international law. The conference suggested closing the Tribunal immediately and revising all its decisions "in accordance with general legal procedures" (pp. 305-306). Long annexes to the monograph are also worth mentioning as they contain statistics on cases tried by the ICTY, specifying the ethnicity of the accused, their status, and the sentences passed as of 2008. The annexes also include the Belgrade District Court's verdict on "the leaders of NATO and European countries that participated in the NATO aggression against Yugoslavia," a list of the accused, a list of persons killed and wounded, and a list of property damaged or destroyed as a result of the NATO operation (pp. 313-543).

In 2018, a monograph was published by E.M. Minin, a diplomat who worked at the Russian Embassy in the Netherlands in the late 1990s and early 2000s, entitled "Whom the International Criminal Tribunal for the Former Yugoslavia Judged, for What and How." While in diplomatic service, Minin monitored the Tribunal's activities and Dutch media publications, and communicated with the Tribunal staff. Minin believes that the creation of the ICTY and the Tribunal for Rwanda by UN Security Council resolutions was "a gross violation of the UN Charter" because "for this reason [they] have become not so much mechanisms of justice as symbols of injustice and lawlessness" (p. 99). In assessing the Tribunal's performance, the diplomat cites conviction and acquittal statistics and accuses the ICTY of direct involvement in the death of fifteen accused persons, including Milošević (p. 100). He also cites the trial of V. Šešelj as proof of the "disingenuous policy of the Westoriented ICTY" (p. 103). Some chapters are devoted to the trials of Milošević, Karadžić and Mladić. The diplomat quotes Milošević's words addressed to the "Russians" (including residents of Ukraine and Belarus), warning them of the danger of their division by Western countries. The diplomat believes that the validity of Milošević's warning is borne out by events in Ukraine. Minin doubts the genocide against 
Bosnian Muslims (pp. 133-135) and refers to the ICTY decision to drop all charges against Milošević, which is not true (ICTY, 2016).

So, the legitimacy of the ICTY and the ICTR is another debatable issue, and its interpretation varies depending on which particular problems of the Tribunals are discussed. For some, the legitimacy of the Tribunal is questionable due to the lack of a founding treaty (Guskova, 2012; Mikhailov, 2004; Nelaeva and Gizatullina, 2012) and because of its substantive, temporal, and territorial jurisdiction (Minin, 2018). Other experts criticize the Tribunal's competence, the way the investigations were carried out and charges brought, as well as violations of the rights of the accused (Mikhailov, 2006; Mezyaev, 2007). Some Russian experts note that the practice of indictment under seal was not lawful (Ryzhkov and Tetekin, 2005; Minin, 2018; Vedernikova, 2009). This practice was used to apprehend some of the accused when the indictment was announced after the arrest. This is how Krajina Serb Slavko Dokmanović, former mayor of Vukovar, and Milan Kovačević, former president of the Executive Committee of the Municipal Assembly of Prijedor, were arrested. Both died in prison in The Hague in the summer of 1998. Mary Robinson, UN High Commissioner for Human Rights at that time, drew attention to these cases. Doubts were raised about the legality of the "joint criminal enterprise" doctrine, which had been used for indicting political leaders of the countries involved in the armed conflict in Bosnia and Herzegovina (Nelaeva and Gizatullina, 2012, p. 78).

In her book, Carla Del Ponte, former ICTY prosecutor (1999-2007), also wrote about the problem of the Tribunal's legitimacy and limited jurisdiction, and noted that the Tribunal's work "took place along the edge of the divide between national sovereignty and international responsibility, in the gray zone between the judicial and the political" (Del Ponte, 2011, p. 15). It is worth noting that Del Ponte's book was translated into Russian, as was the book of John Laughland of Britain (2007), who called the Tribunal a "travesty." In his opinion, the Tribunal's work testified to the emergence of new globalist "human rights" regimes and signified that "international law would lose its 'horizontal' and consensual structure and become vertically structured 
and coercive" (p. 60). The arguments presented by G.A. Nelaeva and Z.I. Gizatullina (on the reasons for the limited competence of the Tribunal, which Del Ponte also wrote about) are quite important: many states refused to cooperate with the Tribunal in the beginning; there were funding and recruitment problems; and some countries refused to provide access to the burial sites of the victims of crime, interview witnesses, and extradite suspects (2012, p. 76).

Russian experts critically assess the ICTY's effectiveness in accordance with its mandate: restoring justice for victims of war crimes, punishing criminals, preventing such crimes in the future, and reconciling peoples (Guskova, 2009). This opinion can also be found in the works of Western scholars (Snyder and Vinjamuri, 2004). Russian experts often quote criticisms of the ICTY by Russian government officials. For example, S.A. Yegorov refers to remarks by Vitaly Churkin, Russia's permanent representative at the UN Security Council in 2012, that the ICTY's acquittals "discredit the idea of international criminal justice" and that the Tribunal "manifests neither justice nor effectiveness" (UN Security Council, 2012). Yegorov also quotes Vladimir Chizhov, Russia's permanent representative to the EU since 2005, as saying that the negative consequence of the ICTY's work is "undermining confidence in the entire system of international criminal justice" (Yegorov, 2014, p. 595).

The effectiveness of any international institution depends on the participation of the founding states in its work. Nelaeva and Gizatullina cite Harry Bass' opinion on the contradiction between efficiency and legitimacy: "the closer a tribunal is to the power of the state, the more chances it has to enforce its verdicts. At the same time, the closer a tribunal is to the power of the state, the less impartial it will appear" (Nelaeva and Gizatullina, 2012, p. 76). N.G. Mikhailov (2010) points to a contradiction in the interpretation of the principle of legality in international criminal law and relevant principles of national legal systems. He believes that the obvious goal of international criminal law is to maintain a balance between protecting the interests of justice and ensuring justice for the accused and preserving the world order. In fact, many experts point to the difficulty to solve the dilemma faced by 
international criminal justice between justice and order, and between international law and national interests, including state sovereignty.

In addition to generally critical assessments of the tribunals, Russian experts have also noted positive results of the ICTY's work. They reiterated the value of this experience for the rapid development of international criminal proceedings (Yegorov, 2014, p. 590), which have been "dormant" since the Nuremberg and Tokyo Tribunals (Yesakov, 2016, p. 216). The ICTY's work has also contributed to a practical understanding of the changing nature of current armed conflicts, including humanitarian and peacekeeping operations. Sh.N. Khaziev writes about the invaluable experience gained "in organizing forensic examinations by international teams of forensic experts in extreme conditions, and amid political instability in the region and the massive media impact on the population and participants in the investigation" (2016, p. 108).

G.A. Nelaeva points out that the work of the UN tribunals facilitated the inclusion of new types of crimes in the category of war crimes, which have long been ignored by the international community. This applies to sexual crimes since this type of crime is not recorded in IHL. Nelaeva speaks of rule-making by way of "soft law" resulting from resolutions of international organizations and decisions of international courts and tribunals (Nelaeva, 2007, 2014). According to S.Yu. Marochkin and G.A. Nelaeva, the ICTY helped to bring human rights law and IHL closer together (2013). The work of international tribunals makes it possible to separate the "past from the present" (Nelaeva, 2015, p. 75), to see the political and legal reasons for the inefficiency of international ad hoc tribunals (Nelaeva and Khabarova, 2016, pp. 459-460), and initiate a discussion in the professional community on how to overcome these problems.

The ICTY's work made experts actively discuss the very concept of "international crime" as a synonym of "war crime" within the framework of IHL. G.A. Yesakov believes that the "narrow understanding of international criminal law" is the most correct one and contrasts it with a broader interpretation of international or internationalized crimes, which are "rather national by origin, and 
what really forces them to 'go' in the direction of international criminal law is the fact that in some cases they are complicated with crossborder elements and that the international community is concerned about their prosecution" (Yesakov, 2016, p. 218).

\section{EVALUATING THE WORK OF THE INTERNATIONAL CRIMINAL COURT}

The evolution of the Russian position has been exhaustively described by B.T. Tuzmukhamedov as going from "certainty to the uncertainty of participation and from uncertainty to the certainty of nonparticipation" in the work of the ICC (Tuzmukhamedov, 2019). After Russia signed the Rome Statute in 2000, a special group of experts at the Ministry of Justice worked to ratify the document. One might expect that the problems of legitimacy and effectiveness of the ICTY and the ICTR raised by Russian experts would be taken into account by the ICC; however, the attitude of Russian experts appears to be rather critical, obviously due to political reasons. Russian Supreme Court Judge O.N. Vedernikova has pointed out that "there are numerous intractable legal obstacles that do not allow the Russian Federation to ratify the statute in the near future" (2009, p. 78). In 2012, Vedernikova expressed the opinion that "this court should be a punitive body, but the ICC lacks effectiveness in the absence of proper cooperation with it on the part of states and international organizations" (cited by Abashidze et al., 2012, pp. 10-11).

Many experts have explicitly spoken of the persistent political problems that affect Russia's ability to participate in the work of the ICC and ratify the Rome Statute. I.Yu. Bely notes that the legal regulation of international criminal prosecution for war crimes is one of the main aspects of Russia's foreign and domestic policy due to the current international conditions and the overall situation around Russia, which have forced the country to rethink its foreign and domestic policy priorities. In his opinion, "Russia's substantive interest in the prevention and settlement of armed conflicts should be recognized as a permanent factor of its foreign policy" (Bely, 2015, p. 19). In fact, Bely emphasizes that participation in armed conflicts is a permanent factor of Russia's foreign policy. 
A significant number of works by Russian experts are devoted to practical aspects of the ICC's work, its jurisdiction and the expansion of substantive jurisdiction by including the crime of aggression (Glotova, 2017; Marusin, 2013), special rights and guarantees for women as victims and witnesses of crimes (Trikoz, 2011), the harmonization of human rights with IHL (Lyamin, 2015), and the need to take into account the nature of modern armed conflicts (Volova, 2011). There is an ongoing expert discussion about the concept of international crime and its narrow and broad interpretations (outside the IHL framework), which is important for understanding the ICC's jurisdiction and Russia’s participation in its work (Bogush and Trikoz, 2009; Kostenko, 2017). Experts are also discussing the application of IHL norms in modern armed conflicts, including peacekeeping missions and extradition of suspects. In 2012, the ICC adopted an addendum to the Rome Statute, according to which military personnel have immunity from prosecution during UN peacekeeping missions. However, Russia carries out military operations outside of the UN mandate, and this requires special attention from Russian lawyers in order to ensure that these activities are in line with the country's international obligations.

Russian lawyers are discussing the need to "supplement and amend Russian current legislation (criminal, criminal procedural, and penal)" (Bely and Sokovykh, 2011, p. 10). These problems are examined in detail in the textbook International Law edited by V.I. Kuznetsov and B.T. Tuzmukhamedov (2010). Russian experts write about the need to "specify" IHL norms within the framework of Russian legislation and eliminate contradictions with international and national law (pp. 67-77, pp. 658-661). S.Yu. Marochkin notes the complexity of the relationship between international and Russia's criminal law, and cites introductory articles in the Russian Criminal Code which postulate that the Criminal Code "is based on the Constitution of the Russian Federation and universally recognized principles and norms of international law" (Article 1), while the principle of legality (Article 3) states that "the criminality of an act as well as its punishability and other criminal legal consequences, are determined solely by this Code" (Kuznetsov and Tuzmukhamedov, 2010, p. 75). Marochkin refers to the 
decision of the Plenum of the Russian Supreme Court of October 10, 2003, which specifically stipulates the possibility of direct application of an international treaty to the norms of the Criminal Code and cites Article 355 "Development, Production, Stockpiling, Acquisition or Sale of Weapons of Mass Destruction" and Article 356 "The Use of Prohibited Means and Methods of Warfare," that is, essentially IHL norms, as an example. Indeed, IHL norms are included in the Russian Criminal Code adopted in 1996 and constantly supplemented almost annually. Section XII of the Criminal Code "Crimes Against Peace and Security of Humankind" includes nine articles. Article 356 "The Use of Prohibited Means and Methods of Warfare" briefly lists the main war crimes without detailing them. Article 357 of the Criminal Code defines the crime of genocide. However, these crimes have never been specified in national law, although in May 2014, Article 354 "Public Calls for an Aggressive War" was supplemented with a paragraph on "the rehabilitation of Nazism," and in July 2016, Section XII of the Russian Criminal Code was amended to include Article 361 "Acts of International Terrorism."

Russian lawyers say that the "lasting 'blank spots"' always prompt one to bear in mind the clause made by prominent Russian diplomat and lawyer F.F. Martens, according to which in cases not provided for in the said branch of law "civilians and combatants remain under the protection of international law and its tenets arising from the established customs, the principles of humanity and the requirements of public consciousness" (Kuznetsov and Tuzmukhamedov, 2010, pp. 660-661).

Russia's refusal to become a member of the ICC can be explained by the latter's investigation of the accession of Crimea and Sevastopol into the Russian Federation and the start of hostilities in Eastern Ukraine (International Criminal Court, 2019, pp. 66-72). The Ukrainian government has repeatedly asked the ICC to investigate the events in Crimea and Eastern Ukraine, and in 2014 the ICC prosecutor decided to start a preliminary examination (International Criminal Court, 2017). In November 2016, the ICC prosecutor's annual report assessed the annexation of Crimea as occupation and the beginning of an 
international armed conflict between Russia and Ukraine (International Criminal Court, 2016, pp. 158-170). It is worth mentioning that, just like Russia, Ukraine has not ratified the Rome Statute. However, if a country outside the Rome Statute makes the relevant request, the ICC can start considering it if such a country recognizes the court's jurisdiction over a particular situation. In addition, the ICC Prosecutor has launched an investigation into the events in South Ossetia in 2008 in accordance with the decision adopted by the Pre-Trial Chamber in 2016 (International Criminal Court, 2016a).

I.Yu. Bely points to the political reasons for Russia's refusal to ratify the Rome Statute, including the United States' non-participation in it and the practice of bilateral agreements between non-member countries and member countries on non-extradition of war crimes suspects (Bely, 2017, p. 65). A.B. Mezyaev believes that Russia's nonparticipation is due to the fact that the ICC is based on the "Western worldview" and the "Western concept of repressive justice," as well as the fact that the Russian Federation is not satisfied with the ICC's work in general, and the way it handles cases against Russia in particular. The expert also indicates the "fundamental legal reasons" for the inconsistencies between the ICC Statute and "the provisions of Russia's national legislation," adding that its ratification would require Russia to amend its Constitution (Mezyaev, 2017, p. 93). G.A. Yesakov claims that Russia's refusal to ratify the Statute is explained by the established perception of international criminal courts as politically biased (2017).

According to B.T. Tuzmukhamedov, who worked as a first instance judge at the ICTR and then in the Appeals Chamber of the International Criminal Tribunals for Rwanda and the former Yugoslavia, one should not expect Russia to take any political or legal action with regard to the Rome Statute. However, the Foreign Ministry's reaction to cases involving the Russian Federation or to the behavior of other countries would be quite expected, thus reflecting Russia's official position on the court's work. At the same time, the expert notes that "the Russian community of lawyers, both scholars and practitioners, is well aware of the Statute and the ICC, including high-level judges." Tuzmukhamedov mentions three judges of the Russian Constitutional Court who have 
referred to the ICC and the Rome Statute in support of their opinions (Tuzmukhamedov, 2019, p. 8).

An analysis of Russian expert publications makes it possible to draw several conclusions regarding the understanding of international criminal courts' practice of criminal prosecution for IHL violations. The number of publications on this topic, including in English, increases every year, signifying an unflagging interest among Russian experts who discuss general problems of international justice, Russia's obligations arising from international agreements, and the incorporation of IHL into national legislation.

Russian experts are generally quite critical of international criminal courts. They believe that the politicization of tribunals and courts is the main problem of international criminal prosecution for IHL violations. The ICTY's work was unsatisfactory for many, and criticism by Russian experts should be viewed as an important basis for improving the system of international criminal courts. Bosnia and Herzegovina remains a symbol of ineffective international peacemaking and international justice. The memorial cemetery where the victims of the Srebrenica massacre are buried is just across the road from the former base of UN peacekeepers who were supposed to protect this security zone. The base has been turned into a kind of memorial center reminding everyone of the international community's inability to protect the victims of armed conflicts, with the entrance sign welcoming the visitors with the words: "Srebrenica genocide-the failure of the international community."

The politicization of international criminal prosecution manifests itself in several ways. The Russian expert community tends to believe that today international criminal justice is too often a hostage to political decisions, which significantly affects the investigation and the trial itself. The reason for Russia's non-participation in the work of the ICC is political disagreements with other countries regarding conflicts in Russia, the settlement of which involved the use of armed force, military missions outside the country and outside the 
UN mandate. Russia's conflicts with the international community regarding political entities in the states that were previously part of the USSR (Moldova, Ukraine, Georgia), as well as the situation of Crimea after 2014 further complicate the situation both politically and legally. G.I. Bogush notes that "unfortunately, international criminal law is one of the extremely politicized areas where academic discussion is replaced with a political one, and legal arguments are substituted by ideological clichés (needless to say, this happens not only in Russia)" (2016, p. 208). This means that Russia will continue to use mainly the national level to fulfill its obligations under IHL, emphasizing the consensus principle of international law and the fact that the international level is "complementary" and performs a deterrent role (Tikhomirov, 2013). Russia is unlikely to cooperate with the ICC on cases initiated against its citizens.

Another frequently discussed problem is the incorporation of IHL norms into Russian legislation. Experts note that IHL is not detailed in Russian legislation, (Tuzmukhamedov, 2003; Bogush, Yesakov and Rusinova, 2019), that terminological problems arise when provisions of international law are translated from English and French into Russian (Yesakov, 2016; Ivanenko, 2016), that there are serious problems with personnel training in this area, lack of qualified lecturers, instructional and methodological literature, and insufficient teaching hours (Ivanenko, 2016). Bogush notes that "Russian legislation in this area is a poorly systematized small array of non-working norms," which largely use the language of Nuremberg Trials and ignore the rapid development of IHL over the past twenty years (2016, p. 206). Bogush blames this on the inactivity of the Russian Investigative Committee, "the lack of professionalism and basic knowledge in the field of international law among most Russian law enforcement officers" and "our lagging behind in the academic sphere." He believes that Russia can "catch up" by bringing its legislation in line with international criminal law, training law enforcement specialists, and creating an academic and educational environment in the field of international criminal law $(2016$, p. 207). There are also alarmist assessments of the state 
of this branch of law in Russia (Glebov, 2013) and its serious lagging behind "modern international and comparative and legal experience" (Yesakov 2016, p. 219).

Undoubtedly, a community of experts in international criminal law and international humanitarian law is forming in Russia. The International Committee of the Red Cross plays an important role in increasing the expertise of Russian lawyers by providing an extensive IHL educational program and holding annual F.F. Martens competitions for students in a moot court format. Similar active methods of training use the ICC model (Yesakov, 2012). In the past, the limited participation of Russian specialists in the work of the ICTY was explained not only by Russia’s critical official position, but also by the lack of qualified personnel speaking two working languages of the Tribunal-English and French.

The work on this article exposed deep disagreements in the Russian expert community over the relationship between IHL and international criminal law, as well as over international criminal justice in general. Some experts openly speak about a conflict between reformers and conservatives over the incorporation of IHL norms into national legislation and the correlation between the international and national levels of prosecution for international crimes (Kibalnik, 2019).

International criminal justice is at the intersection of politics and law, constantly producing dilemmas. For lawyers, the impartiality of justice institutions and strict adherence to the "letter of the law" are important. In the interests of justice, a court should be as free as possible from any type of dependence and influence. This problem is not always effectively solved at the national level, while at the international level it is exacerbated by the fact that cooperation between states and international courts depends on the incumbent political elites and their willingness to be "triable." This makes international courts a priori dependent on the actions of nation-states. In addition, international courts are financed by states parties to international treaties. The judiciary can only be effective if it is independent from governmental institutions and funding problems. This is an axiom for both national and international justice. 
For the international criminal justice system to function efficiently, the established international institutions need legitimacy, which they lack due to their rejection by some international actors and due to contradictions in the interpretation of norms and principles. International law allows countries to selectively accede to international treaties, such as the Rome Statute of the ICC. According to O.N. Vedernikova, a serious obstacle to the development of international criminal justice is "the absence of a global consensus on the key concepts of modern international criminal justice, which include such categories as order and justice, state sovereignty and the rule of law, and some others, rather political than criminal and legal, which are of fundamental importance for international criminal justice... In the absence of such a consensus, international criminal justice lacks legitimacy and is unable to achieve its objectives" (2012, pp. 220-221).

Russia's participation in the development of international criminal justice is possible and necessary at several levels: official, academic, and professional law enforcement. It is important that law stop being "dormant" and become effective. Focusing on the imperfections of existing international criminal justice institutions cannot solve the problems that are of interest to the Russian state, the professional community and society which itself is subject to protection by law. Russia's self-withdrawal from the development of interstate cooperation in the field of international criminal justice is not an effective way to deal with the imperfections of international justice institutions. The system can improve and take Russian experts' opinion into account only by engaging the Russian professional community in the work of international institutions in various capacities.

International law derives from the practice of international relations and reflects the changes in them, for which the international community is or is not prepared, as well as national legal systems that incorporate and apply the norms of international law. Russia's non-participation in the work of the ICC does not mean that it rejects IHL norms and gives up its obligations under IHL. Rather, it means that there is a complex political and professional discussion underway on the implementation 
and interpretation of IHL principles and on the conformity of national legislation and prosecution practices with international obligations. In fact, this is borne out by the continuing work of Russian lawyers to address issues of international justice and international law as an important area of training for Russian legal experts.

\section{References}

Abashidze A.H. et al., 2012. X yezhegodnaya vserossiyskaya nauchnoprakticheskaya konferentsiya "Aktualnye problemy sovremennogo mezhdunarodnogo prava" (Moskva, 13-14 aprelya 2012 g.) [Annual AllRussian Scientific-Practical Conference "Topical Problems of Contemporary International Law", Moscow, April 13-14, 2012]. Evraziysky yuridichesky zhurnal, 8(51), pp. 9-13.

Bely, I., 2015. Vklyuchyonnost' Rossii v sistemu mezhdunarodnogo ugolovnogo pravosudiya po delam o voennykh prestupleniyakh [Russia's Involvement in the International Criminal Justice System for War Crimes]. Grazhdanin i pravo, 9(9), pp. 17-31.

Bely, I., 2017. Mezhdunarodnoye ugolovnoye pravosudiye i problemy pravovogo suvereniteta Rossii [International Criminal Justice and Problems of Russia's Legal Sovereignty]. Vestnik voyennogo prava, 3(3), pp. 63-67.

Bely, I. and Sokovikh, Yu., 2011. Osnovnye problemy stanovlenyia i perspektivy razvitiya mezhdunarodnogo ugolovnogo sudoproizvodstva po delam o voyennykh prestupleniiakh [Main Problems of the Establishment and Prospects of the Development of International Criminal Jurisdiction for War Crimes]. Vestnik moskovskogo gosudarstvennogo lingvisticheskogo universiteta, 629(629), pp. 7-11.

Bogush, G., 2016. Implementatsiya mezhdunarodnogo ugolovnogo prava v Rossii: naverstyvaya upushchennoe [Implementation of the International Criminal Law in Russia: Making Up for Lost Time]. Rossiysky yezhegodnik mezhdunarodnogo prava, S(S), pp. 206-212.

Bogush, G., Yesakov, G. and Rusinova, V. (eds.), 2019. Mezhdunarodnye Prestupleniya [International Crimes]. 2nd Edition. Moscow: Prospect.

Bogush, G. and Trikoz, E. (eds.), 2009. Mezhdunarodnoye ugolovnoye pravosudiye: sovremennye problemy [International Criminal Justice: Contemporary Issues]. Moscow: Institut prava i publichnoi politiki. 
Del Ponte, C., 2005. The Prosecutor of the Tribunal against Ramush Haradinaj, Idriz Balaj, Lahi Brahimaj. Indictment. Case No:IT-04-84-I. ICTY [online]. Available at: www.icty.org/x/cases/haradinaj/ind/en/har-ii050224e.pdf [Accessed 1 November 2021].

Del Ponte, C., 2008. Okhota. Ya i voyennye prestupniki [The Hunt: Me and the War Criminals]. Translated by T. Novikova and S. Artemov. Moscow: Eksmo.

Del Ponte, C., Sudetic, Ch., 2011. Madame Prosecutor: Confrontations with Humanity's Worst Criminals and the Culture of Impunity. New York: Other Press.

Deriglazova, L., 2007. Mezhdunarodnoye sudebnoye i vnesudebnoye pravosudiye [International Criminal and Extrajudicial Justice]. Mezhdunarodnye protsessy, 5(1(13)), pp. 38-53.

Dzhantaev, Kh., 2013. Voyenny prestupnik Ratko Mladich vydan Serbiei Mezhdunarodnomu tribunalu v Gaage [War Criminal Ratko Mladić Extradited by Serbia to the International Tribunal in The Hague]. Voprosy gumanitarnykh nauk, 2(65), pp. 53-59.

Glebov, I., 2013. K 35-letiyu Dopolnitenyh protokolov k Zhenevskim konventsiyam o zashchite zhertv voiny [To the 35th Anniversary of the Additional Protocols to the Geneva Conventions for the Protection of Victims of War]. Evraziysky yuridichesky zhurnal, 5(60), pp. 140-144.

Glotova, S., 2017. Yurisdiktsiya mezhdunarodnogo ugolovnogo suda v otnoshenii prestupleniya agressii [Jurisdiction of the International Criminal Court with Regard to the Crime of Aggression]. Vestnik Volzhskogo universiteta im. V.N. Tatishcheva, 2(4), pp. 45-53.

Guskova, E., 2003. Perekrestny dopros: Tribunal v Gaage. Zametki svidetelya [Cross-Interrogation: The Hague Tribunal. Witness's Notes]. Rodina, 10(10), pp. 122-123.

Guskova, E., 2009. Deyatelnost' Mezhdunarodnogo tribunala po byvshei Yugoslavii (MTBIU): soderzhaniye, rezultaty, effektivnost' [Activities of the International Tribunal for the Former Yugoslavia (ICTY): Content, Results, Effectiveness]. Novaya i noveyshaya istoriya, 5(5), pp. 252-253.

Guskova, E. (ed.), 2012. Mezhdunarodny tribunal po byvshei Yugoslavii: deyatelnost', rezultaty, effektivnost': materialy mezhdunar. nauch. konf. (Moskva, 22-23 apr. $2009 \mathrm{~g}$.) [International Tribunal for the Former Yugoslavia: Activities, Results, Effectiveness: Materials of the International Scientific Conference. Moscow, April 22-23, 2009]. Moscow: Indrik. 
Hirsch, F., 2020. Soviet Judgment at Nuremberg. A New History of the International Military Tribunal after World War II. Oxford University Press.

ICTY, 2016. Prosecutor vs Radovan Karadzic. Public redacted version of judgment issued on 25 March 2016. Case No IT-95-5/18-T. International Criminal Tribunal for the Former Yugoslavia, 25 March [online]. Available at: www.icty.org/x/cases/karadzic/tjug/en/160324_judgement.pdf [Accessed 30 June 2020].

International Criminal Court, 2016. Otchet o deistviyakh po predvaritelnomu rassledovaniyu (2016 g.) [Preliminary Investigation Action Report (2016)]. The Office of the Prosecutor. International Criminal Court, 14 November [online]. Available at: www.icc-cpi.int/iccdocs/otp/161114-otp-rep-PE-Ukraine.pdf [Accessed 22 July 2020].

International Criminal Court, 2016a. Situation in Georgia. ICC-01/15. International Criminal Court, 27 January [online]. Available at: www.icc-cpi. int/georgia [Accessed 22 July 2020].

International Criminal Court, 2017. Ukraine. International Criminal Court [online]. Available at: www.icc-cpi.int/itemsDocuments/2017-PE-rep/2017-otprep-PE-Ukraine_ENG.pdf [Accessed 29 July 2020].

International Criminal Court, 2019. Report on Preliminary Examination Activities (2019). The Office of the Prosecutor. International Criminal Court, 5 December [online]. Available at: www.icc-cpi.int/itemsDocuments/191205rep-otp-PE.pdf?fbclid=IwAR2LjynJd6A-ArmS5DMgAKWjd_ZRXDYx3_ wveMJU8trlmIoI9dLLtVi9ly8 [Accessed 29 July 2020].

Ivanenko, V., 2016. Prepodavanie mezhdunarodnogo gumanitarnogo prava $\mathrm{v}$ vysshikh uchebnykh zavedeniiakh Rossii: stanovlenie, problemy, resheniya [Teaching International Humanitarian Law in Higher Educational Institutions in Russia: Formation, Challenges, Solutions]. Rossiysky yezhegodnik mezhdunarodnogo prava, S(S), pp. 96-125.

Khaziev, Sh., 2016. Sudebnye ekspertizy v deyatelnosti Mezhdunarodnogo ugolovnogo tribunala po byvshei Yugoslavii [Forensic Expertise in the International Criminal Tribunal for the Former Yugoslavia]. Teoriya i praktika sudebnoi ekspertizy, 3(43), pp. 100-109.

Kibalnik, A., 2019. K voprosu o znachimosti resheniy mezhdunarodnyh ugolovnykh tribunalov v ramkakh doktriny mezhdunarodnoi (natsionalnoi) ugolovnoi yustitsii [On the Relevance of Decisions of International Criminal Tribunals within the Framework of the Doctrine of International (National) 
Criminal Justice]. Intellektualnye resursy - regionalnomu razvitiyu, 5 (3), pp. 54-63.

Kostenko, N., 2017. Rol' mezhdunarodnoi ugolovnoi yustitsii v vypolnenii zadach mirovogo soobshchestva - OON [The Role of International Criminal Justice in the Implementation of the Tasks of the World Community-The UN]. Rossiysky zhurnal pravovykh issledovaniy, 3(12), pp. 87-96.

Kuznetsov, V. and Tuzmukhamedov, B. (eds.), 2010. Mezhdunarodnoye pravo [International Law]. 3rd Edition. Moscow: Norma.

Laughland, J., 2007. Travesty: The Trial of Slobodan Milosevic and the Corruption of International Justice. London: Pluto Press.

Lyamin, N., 2015. Primenenie Mezhdunarodnym ugolovnym sudom norm mezhdunarodnogo gumanitarnogo prava i mezhdunarodnogo prava cheloveka [Application of the Norms of International Humanitarian Law and International Human Rights Law by the International Criminal Court]. Sovremennoye pravo, 6(6), 144-148.

Marochkin, S. and Nelaeva, G., 2015. The Changing Dynamics of International Lawmaking: Trying Heads of State for Rape and Sexual Violence. The Law and Practice of International Courts and Tribunals, 14(2), pp. 290-304. doi. org/10.1163/15718034-12341294

Marochkin, S. and Nelaeva, G., 2016. Studying "Russian Approaches to International Law": Eurocentrist Traps, Civilisational Dilemmas and Political Ambiguities. Nordic Journal of International Law, 85(4), pp. 395-403. doi. org/10.1163/15718107-08504008

Marusin, I., 2013. Opredeleniye agressii v Statute Mezhdunarodnogo ugolovnogo suda i Ustave Nyurnbergskogo tribunala [Definition of aggression in the Statute of the International Criminal Court and in the Charter of the Nuremberg Tribunal]. Izvestiya vysshikh uchebnykh zavedeniy. Pravovedenie, 4(309), pp. 112-120.

Mezyaev, A., 2007. Mezhdunarodny tribunal po byvshei Yugoslavii [International Tribunal for the Former Yugoslavia: Legal Aspects]. Rossiysky yuridichesky zhurnal, 2(54), pp. 46-49.

Mezyaev, A., 2011. Nyurnberg: tolko li istoriya? Yavlyaetsya li Gaaga preemnikom Nyurnberga? [Nuremberg: Is It Merely History? Is the Hague the Successor of Nuremberg?]. Publichnoye i chastnoye parvo, 4(12), pp. 27-32.

Mezyaev, A., 2017. Mezhdunarodno-pravovye aspekty resheniya Rossii ne stat' uchastnikom Statuta Mezhdunarodnogo ugolovnogo suda [International 
Legal Aspects of Russia's Decision Not to Become a Party to the Statute of the International Criminal Court]. Mezhdunarodnoye pravo i mezhdunarodnye organizatsii, 3(3), pp. 84-93.

Mikhailov, N., 2003. Mezhdunarodny tribunal po byvshei Yugoslavii. O samostoiatelnosti, nezavisimosti i bespristrastnosti [International Tribunal for the Former Yugoslavia. On Autonomy, Independence, and Impartiality]. Obozrevatel, 11(166), pp. 90-100.

Mikhailov, N., 2004. O legitimnosti Mezhdunarodnogo tribunala po byvshei Yugoslavii [On the Legitimacy of the International Tribunal for the Former Yugoslavia]. Obozrevatel, 1(168), pp. 115-123.

Mikhailov, N., 2006. Mezhdunarodny ugolovny tribunal po byvshei Yugoslavii: kompetentsiya, istochniki prava, osnovnye printsipy deyatelnosti [International Criminal Tribunal for the Former Yugoslavia: Competence, Legal Sources, Main Principles of Activity]. Moscow: Dom Shumilovoi I.I.

Mikhailov, N., 2010. Printsip zakonnosti v tolkovanii sudei Mezhdunarodnogo tribunala po byvshei Yugoslavii [The Principle of Legality in the Interpretation by Judges of the International Tribunal for the Former Yugoslavia]. Gosudarstvo i pravo, 4(4), pp. 63-70.

Minin, E., 2018. Kogo, za chto i kak sudil Mezhdunarodny tribunal po byvshei Yugoslavii [Whom, Why and How the International Criminal Tribunal for the Former Yugoslavia Judged]. Moscow: FGBOU MGLU.

Nelaeva, G., 2007. Prosecution of Rape and Sexual Assaults as International Crimes: Explaining Variation. PhD thesis (Political Science). Budapest: Central European University.

Nelaeva, G., 2010. The Impact of Transnational Advocacy Networks on the Prosecution of Wartime Rape and Sexual Violence: The Case of the ICTR. International Social Science Review, 85(1/2), pp. 3-27.

Nelaeva G., 2014. "The Path Towards Justice for Victims of Sexual Violence”? International Responses to Wartime Rape in the International Criminal Tribunal for the Former Yugoslavia (ICTY). Journal of Kaleidoscope, 5(9), pp.194-209.

Nelaeva, G., 2015. Sovremennye diskussii o mezhdunarodnykh tribunalakh: Mezhdunarodny tribunal po byvshei Yugoslavii v otsenkakh ekspertov i sotrudnikov [Contemporary Debate over International Criminal Tribunals: International Criminal Tribunal for the Former Yugoslavia as Seen by Experts and Tribunals' Staff.]. Sotsium i vlast', 4(54), pp. 72-77. 
Nelaeva, G. and Gizatullina, Z., 2012. Politiko-pravovye aspekty sozdaniya Mezhdunarodnogo tribunala po byvshei Yugoslavii [Political and Legal Aspects of the Establishment of International Court for the Former Yugoslavia]. Mirovaya ekonomika i mezhdunarodnye otnosheniya, 1(1), pp. 72-80.

Nelaeva, G. and Khabarova, E., 2016. Otsenki deyatelnosti Mezhdunarodnogo tribunala po byvshei Yugoslavii: vzglyady rossiyskikh i zarubezhnykh ekspertov [Assessments of the International Tribunal Performance for the Former Yugoslavia: Views of Russian and Foreign Experts]. Mezhdunarodnoye pravo i mezhdunarodnye organizatsii, 4(4), pp. 457-464. DOI: 10.7256/22266305.2016.4.20844

Primakov, Ye. 2009. "V byvshei Yugoslavii vsyo vremya budet "plavayushchaya stabilnost" [Ye. Primakov: "Floating Stability to Persist in the Former Yugoslavia]. Interview. Vesti.Ru, 25 March [online]. Available at: www.vesti.ru/ article/2194096 [Accessed 21 May 2020].

Ryzhkov, N. and Tetekin, V. (eds.), 2005. Govoryat svideteli zashchity: Sud nad Slobodanom Miloshevichem [Defense Witnesses' Testimony: The Trial of Slobodan Milošević]. Moscow: Veche.

Snyder, J. and Vinjamuri, L., 2004. Trials and Errors: Principle and Pragmatism in Strategies of International Justice. International Security, 28(3), pp. 5-44. DOI: $10.1162 / 016228803773100066$

Tikhomirov, Yu., 2013. Pravovoi suverenitet: sfery i garantii [Legal Sovereignty: Spheres and Guarantees]. Zhurnal rossiyskogo prava, 3, pp. 5-22.

Trikoz, E., 2011. Gendernye aspekty mezhdunarodnogo ugolovnogo pravosudiya [Gender Issues in International Criminal Jurisdiction]. Mezhdunarodnoye pravosudiye, 1(1), pp. 98-110.

Tuzmukhamedov, B., 2003. The Implementation of International Humanitarian Law in the Russian Federation. Revue Internationale de la Croix-Rouge/ International Review of the Red Cross, 85(850), pp. 385-396.

Tuzmukhamedov, B., 2019. Russia and the International Criminal Court: From Uncertain Engagement to Positive Disengagement. SSRN Electronic Journal. Available at: dx.doi.org/10.2139/ssrn.3339809 [Accessed 10 August 2020].

UN Security Council, 2012. 6880th Meeting. S/PV.6880. United Nations Security Council, 5 December [online]. Available at: undocs.org/ru/S/PV.6880 [Accessed 13 July 2020].

U.S. Sanctions, 2020. U.S. Sanctions on the International Criminal Court. 14 December 2020. Human Rights Watch. Available at: www.hrw.org/ 
news/2020/12/14/us-sanctions-international-criminal-court [Accessed 1 November 2021].

Vasiliyev, S. and Ogorodova, A., 2005. Implementation of the Rome Statute in Russia. Finnish Yearbook of International Law, 16(16), pp. 197-234.

Vedernikova, O., 2009. Rimskiy Statut Mezhdunarodnogo ugolovnogo suda: kritichesky analiz [The Rome Statute of the International Criminal Court: Critical Analysis]. Gosudarstvo i pravo, pp.70-78.

Venice Commission, 2020. Opinion N. 981/2020. Russian Federation Opinion on the Draft Amendments to the Constitution (Signed by the President of the Russian Federation on 14 March 2020) Related to the Execution in the Russian Federation of Decisions by the European Court of Human Rights. European Commission for Democracy through Law (Venice Commission), 18 June [online]. Available at: www.venice.coe.int/webforms/documents/default. aspx?pdffile=CDL-AD(2020)009-e [Accessed 25 June 2020].

Volevodz, A., 2016. Itogi Nyurnbergskogo protsessa i vyzovy sovremennosti: materialno-pravovoi aspekt [The Results of the Nuremberg Trial and Modern Challenges: The Substantive Law Aspect]. In: SKRF Academy, Itogi Nyurnbergskogo protsessa i vyzovy sovremennost $i$ [The Results of the Nuremberg Trial and Modern Challenges], Moscow, 24 November. Moscow: Moskovskaya akademiya Sledstvennogo komiteta Rossiyskoi Federatsii.

VTSIOM, 2006. Slobodan Miloshevich: geroi ili prestupnik? [Slobodan Milošević: A Hero or a Criminal?]. VTsIOM, 23 March [online]. Available at: wciom.ru/index.php?id=236\&uid=2876 [Accessed 15 July 2020].

Yegorov, S., 2014. Mezhdunarodny tribunal po byvshei Yugoslavii [International Criminal Tribunal for the Former Yugoslavia]. Mezhdunarodnoye pravo $i$ mezhdunarodnye organizatsii, 4(4), pp. 581-597. DOI: 10.7256/22266305.2014.4.12303.

Yesakov, G., 2012. Model mezhdunarodnogo ugolovnogo suda v Rossii [International Criminal Court Proceedings Model in Russia]. Mezhdunarodnoye pravosudie, 2(3), pp. 124-129.

Yesakov, G., 2016. Mezhdunarodnoye ugolovnoye pravo i doktrina rossiyskogo ugolovnogo prava [International Criminal Law and the Doctrine of the Russian Criminal Law]. Rossiysky yezhegodnik mezhdunarodnogo prava, pp. 212-233.

Yesakov, G., 2017. International Criminal Law and Russia: From 'Nuremberg' Passion to 'The Hague' Prejudice. Europe-Asia Studies, 69(8), pp. 1184-1200. DOI: 10.1080/09668136.2017.1377156 